\title{
Ecophysiology of coconut palm under water stress
}

\author{
Fábio P. Gomes ${ }^{1 *}$ and Carlos H.B.A. Prado ${ }^{2}$ \\ ${ }^{1}$ Departamento de Ciências Biológicas, Universidade Estadual de Santa Cruz, 45662-000 Ilhéus, BA, Brasil. ${ }^{2}$ \\ Departamento de Botânica, Universidade Federal de São Carlos, 13565-905 São Carlos, SP, Brasil. * Corresponding \\ author:gomes@uesc.br
}

Received: 01 November 2007; Accepted: 12 December 2007

\begin{abstract}
Coconut palm is of great social and economic importance for millions of people in the tropics and subtropics. Drought is one of the main environmental factors that limit coconut productivity. In this review, physiological and morphological data are presented in an integrated perspective to provide a holistic view of the behavior of coconut trees facing water deficit under both field and controlled conditions. Great capacity to produce homorhizic roots capable of searching continuously for water and nutrients and high protoplasmic tolerance in leaves allows the coconut tree to endure water deficit. High membrane stability, osmoprotection, osmoregulation and enhanced activity of antioxidant enzymes are characteristics often found in leaves of drought-stressed coconut trees. Information on leaf gas exchange, leaf water potential, water-use efficiency and stomatal behavior was compiled highlighting the differences among cultivars and hybrids under water stress. Genotypic differences in physiological and morphological traits can largely explain the agronomic performance of field-grown coconut trees under drought conditions.
\end{abstract}

Key words: Cocus nucifera, desiccation tolerance, leaf gas exchange, leaf water relations, net photosynthesis, osmotic potential, water potential, water-use efficiency

Ecofisiologia do coqueiro sob deficiência hídrica: O coqueiro apresenta grande importância econômica e social para milhões de pessoas nos trópicos e subtrópicos. A seca é um dos fatores ambientes que mais limitam a produtividade do coqueiro. Nessa revisão, apresentam-se dados fisiológicos e morfológicos sob uma perspectiva integrada, de modo a ter-se uma visão holística acerca do comportamento do coqueiro frente à deficiência hídrica em campo e em condições controladas. A elevada capacidade de produzir raízes homorrízicas, a capacidade dessas raízes em prospectar continuamente água e nutrientes e a elevada tolerância protoplasmática nas folhas permitem ao coqueiro superar o déficit hídrico. Elevada estabilidade das membranas, osmoproteção, osmoregulação, e aumento da atividade de enzimas antioxidantes são características usualmente observadas nas folhas do coqueiro sob déficit hídrico. Informações sobre as trocas gasosas foliares, potencial hídrico foliar, eficiência do uso da água e o comportamento estomático foram compiladas, destacando-se as diferenças entre cultivares e híbridos sob estresse hídrico. As diferentes características morfofisiológicas de genótipos de coqueiro geralmente guardam correspondência com as observações agronômicas em campo.

Palavras-chave: Cocus nucifera, eficiênca do uso da água, fotossíntese líquida, potencial osmótico, potencial hídrico, relações hídricas, tolerância à dessecação, trocas gasosas foliares

\section{INTRODUCTION}

Palm species are important components of tropical rain forests and are present in all forest strata (canopy, subcanopy and understorey). There are reports on the occurrence of palms in wet habitats such mangroves, freshwater swamps and seasonally inundated forests. In dry environments they are prominent in dry forests, savannahs and desert oases, but are excluded from environments with freezing temperatures (Tomlinson, 2006). According to Walther et al. (2007), species of the Arecaceae family have been quoted as important

Abbreviations: $C_{\mathrm{a}}-$ atmospheric $\mathrm{CO}_{2}$ concentration; $C_{\mathrm{i}}-$ intercellular $\mathrm{CO}_{2}$ concentration; $E-$ transpiration rate; $g_{\mathrm{s}}-$ stomatal conductance to water vapor; $P_{\mathrm{N}}-$ net photosynthesis; $P_{\mathrm{N}} / g_{\mathrm{s}}-$ intrinsic water-use efficiency; PPFD - photosynthetic photon flux density; RWC - relative water content; WUE - instantaneous water-use efficiency $\left(P_{\mathrm{N}} / E\right)$; VPD - vapor pressure deficit; $\Psi$ - leaflet water potential 
indicators for obtaining information of the past climate in the Earth's history, and have become significant global bioindicators across continents for present-day climate change and the projected global warming of the near future. The presence of palm fossils indicates the ancient tropical climate in the corresponding geological layer. The recent expansion of the global range of palms across various continents (mainly Trachycarpus fortunei, Arecaceae) coincides with current global warming (Walther et al., 2007).

According to Lorenzi et al. (1996), palms bestow exuberance and fascination to the scenery of tropical regions. In part, this is due to their tendency towards gigantism. Indeed, many botanical records indicate they have the widest stems formed by primary growth $(1 \mathrm{~m})$, the largest self-supporting leaves $(25 \mathrm{~m})$, the largest inflorescence $(8 \mathrm{~m})$ and seed $(25 \mathrm{~kg})$, and the longest unrooted aerial stem, ca. $172 \mathrm{~m}$ in climbing palms of the Calamus genus (Tomlinson, 2006). Furthermore, they are an important food resource for many animal species and have great economic value for human populations (Henderson, 2006). Indeed, palm trees are considered distinctive in that they can become tall and long-living trees entirely by primary developmental processes (Henderson, 2006; Tomlinson, 2006). Species such as açaí (Euterpe edulis Mart.), jussara (Euterpe oleraceae Mart.), coconut (Cocos nucifera L.), oil palm (Elaeis guinensis L.) and piassava (Attalea funifera Mart.) are major producers of biomass in tropical forests. They form a group of great agroeconomic importance in the areas where they occur spontaneously or are cultivated (Lorenzi et al., 1996).

Cocos nucifera is a perennial tropical species of the Arecaceae family, one of the most important in the Monocotyledoneae class. The species includes two main varieties, tall and dwarf, corresponding to $C$. nucifera var. 'typica' and C. nucifera var. 'nana', respectively (Satyabalan, 1997; Aragão et al., 2002a). The southeast region of Asia has been the more accepted center of origin of the coconut tree, from where it was disseminated to more than 80 countries, mainly in tropical areas of the world (Harries, 1978; Ohler, 1999a). In Brazil, historical evidence indicates that the tall variety of coconut was first introduced in 1553 and the dwarf variety in 1925 (Siqueira et al., 2002).

The coconut palm sustains the livelihood of millions of people in coastal regions of the tropics and subtropics (Ohler et al., 1999a; Fontes et al., 2003). Philippines, Indonesia, India, Sri Lanka, Thailand, Tanzania, Brazil and Malaysia are the main coconut producing countries, in decreasing order of importance (FAO, 2005). These eight countries together produced more than 46 million of tonnes in 2005 over an area of approximately 9.3 million hectares. In Brazil, coconut crops represent an important source of income for more than 220,000 small producers (Fontes et al., 2003) occupying around 300,000 ha, of which more than $90 \%$ are located in the coastal zone of the northeast states (Cuenca et al., 2002). Dwarf varieties are currently cultivated in irrigated areas of nontraditional regions such as central and southeast regions of Brazil, with an estimated area of 80,000 ha (Fontes and Wanderley, 2006).

Considered as 'the tree of life' the coconut has a great variety of uses. The coir, the fibrous husk of the coconut fruit (mesocarp), can be used in a large number of products, such as ropes and yarns, aquarium filters, car seat covers, flower pots, soundproofing, mulch for plant growing, heat insulation, brushes, bristles, mattresses, door mats and matting, rugs, and carpets (Abad et al., 2002; Carrijo et al., 2002; Nunes, 2002; van Dam et al., 2004). Coconut oil, milk, pulp, and disintegrated coconut can be obtained from the solid albumen of mature fruits (copra), mainly from the tall varieties (Aragão et al., 2002b). Coconut oil occupies an important position in the international market (Buschena and Perloff, 1991) showing potential application as a biofuel (Tan et al., 2004; Cloin, 2007). The inflorescence sap has been used for production of sugar (Levang, 1988; Ranasinghe and Waidyanatha, 2003). The timber has many applications such as in the fabrication of poles, windows, wooden floors, doors and many other wooden articles, and the leaves are used as a covering of huts and simple houses (Mathew et al., 2000). The water of immature fruits (the liquid endosperm of the seed), obtained mainly from dwarf varieties, is an alternative clean, nutritive and healthy drink. Its equilibrated chemical composition results in a natural isotonic solution with a very pleasant flavor (Aragão et al., 2002b).

Coconut palms require hot climates with an annual mean air temperature between $22-34^{\circ} \mathrm{C}$, absence of temperatures below $15^{\circ} \mathrm{C}$, solar radiation incidence of $300-900 \mathrm{~W} \mathrm{~m}^{-2}$, relative air humidity between $60-90 \%$, 
annual mean rainfall above $1500 \mathrm{~mm}$ that is fairly well distributed throughout the year, and annual sunshine duration of $2000 \mathrm{~h}$ (Ohler, 1999b). The amount and especially the distribution of rain are very important for fruit set and growth (Rajagopal et al., 1996). Coconut trees are found in areas where rainfall varies from 1300 to $2500 \mathrm{~mm}$, with $150 \mathrm{~mm}$ being considered the ideal monthly average for adequate growth and productivity of fruits (Rajagopal et al., 1990). Nevertheless, coconut is frequently exposed to soil and atmospheric water deficit because it is a perennial palm with a long productive life span (Rajagopal and Kasturi Bai, 2002).

Drought is a multidimensional factor of stress affecting the plants at various levels of organization, from cell to organ and to whole plant (Lambers et al., 1998). It is a natural climatic phenomenon when less than expected precipitation occurs within a specified period of time (Feng and Zhang, 2005). Drought stress induces various biochemical and physiological responses in plants, and represents one of the most adverse environmental factors of plant growth and production. While edaphic water stress is related to low soil water availability (due to low pluviometric precipitation, low water infiltration, rapid drainage), atmospheric water stress results from high vapor pressure deficit, VPD, due to low relative humidity associated with high air temperature. These stresses generally occur concomitantly, which leads to a rapid dehydration of drought-sensitive plants.

The effects of water deficit on the physiology, growth and productivity of coconut have been widely documented (Repellin et al., 1994; 1997; Rajagopal and Kasturi Bai, 1999, 2002; Prado et al., 2001; Passos et al., 2003; 2005; Azevedo et al., 2006; Gomes et al., 2007). Important findings about the impact of irrigation levels, and meteorological parameters on the physiology and biochemistry of coconut have also been reported (Kurup et al., 1993; Miranda et al., 1998; Nogueira et al., 1998). Research on water relations in coconut have shown interesting results such as the response of palm to seasonal (Voleti et al., 1993; Shivashankar et al., 1993; Prado et al., 2001; Passos et al., 2003, 2005), or experimental (IRHO-CIRAD, 1992; Repellin et al., 1994; Kasturi Bai et al., 1997; Gomes et al., 2007) water deficit or to osmotic stress (Braconnier and d'Auzac, 1990; Silva Junior et al., 2002). These reports indicated aspects such as stomatal control of water status in stressed and non- stressed plants, as well as the search and validation of morphological, physiological and biochemical indicators of drought tolerance, as potential criteria for breeding and selection of tolerant genotypes. This review provides a framework of present knowledge about the ecophysiological responses of coconut to water deficit. It focuses on morphological, anatomical, physiological and biochemical traits of the coconut palm facing water stress under field and controlled conditions, and their relationship to whole plant tolerance to dehydration (Figure 1). The impact of water shortage on water-use efficiency (WUE) and net rate of photosynthesis $\left(P_{\mathrm{N}}\right)$ along the day and year is discussed together with suggested practices that could mitigate the negative effects of edaphic and/or atmospheric drought in field.

\section{ANATOMICAL AND MORPHOLOGICAL TRAITS LINKED TO DROUGHT TOLER- ANCE}

In coconut palm, only a single stem growth unit is present since palms rarely show branching. The growth unit is defined as a shoot resulting from a terminal or axillary bud during a continuous growth cycle (Hallé et al., 1978). Palms are able to produce tall and centenary stems entirely from the development of cells derived from the apical meristem. Axial vascular bundles of xylem and phloem in the stem are organized in close juxtaposition with extensive interconnection by vascular bridges minimizing isolated functional sectors of mass flux from roots to canopy. Therefore, the stem cross-sectional area is occupied by interconnected vascular bundles retaining conductive ability throughout the life span of the palm (Tomlinson, 2006). The transport capacity of this massive hydrosystem increases by the cube of the stem diameter, whose cells are able to retain their viability over a century. Hence, the stem highly integrates the whole organism, being central for coordinating processes that enable coconut to withstand water stress (Figure 1). It is noteworthy that the continual addition of appendages (roots, leaves, inflorescences) to a single metabolic stem resembles the closed (unitary) growth of most animals rather than the open (modular) growth of most plants (Tomlinson, 2006).

The role of coconut stem as a water conductor and capacitor was demonstrated in a study on the oscillation 
of stem girth as measured by dendrometry. In that study, Passos and Silva (1991) showed that the stem girth of tall coconut decreases between dawn and midday before increasing again during the afternoon in an evident transfer of water from stem to leaves along the day. Moreover, girth variation decreased during daily cycles along the subsequent week after a peak of rainfall, showing that stem refilling along the day is limited by water availability in the rhizosphere. The fruits, whose removal markedly enhanced the amplitude of oscillation of the stem, were considered as an extra reserve of water (Passos and Silva, 1991). The arborescent palm Sabal palmetto stores water in the stem, and this may play an important role in tree survival during periods of low water availability. In this species, the ratio of the amount of water stored within the stem to the leaf area increased linearly with plant height (Holbrook and Sinclair, 1992). Therefore, the amount of water in the stem in relation to leaf area could vary significantly from tall to dwarf coconut palm genotypes. The importance of the stem as a water reserve compartment was discussed by Villalobos et al. (1992) in a study with oil palm. Contrary to adults, young individuals of oil palm were not able to preserve their leaf water status under severe water deficit, since they do not have a voluminous stem and an extensive root system.

The enlargement of the stem base in some palm species is partially due to growth of the root system that forces out the tissues at the stem base (Tomlinson, 1961). In coconut, this enlargement is often observed in tall as well as in some dwarf genotypes, mainly when cultivated under favorable conditions (Satyabalan, 1997). An advantage of stem base enlargement is that it offers additional stability in regions subjected to storms, strong winds and hurricanes (Tomlinson, 1961). On the other hand, drought, flooding, mineral deficiency and some diseases may lead to decreases of the stem diameter, but this may increase again when the environmental conditions normalize. Thus, the stem form and diameter may serve as an indicator of the edaphoclimatic record of the palm's life (Passos, 1998).

Naresh Kumar et al. (2000) described leaflet anatomical adaptations for drought tolerance. Several water stress-related features were found in coconut leaflets as follows: waxy cuticle on the upper epidermis about two-fold thicker than on the lower epidermis, thicker cuticle at the edge, water tissue with thin-walled cells at the upper and lower angles of the straightened leaflet margin, xylem tracheids with thick lignifications, fibrous sheet encircling seven to eight large vascular bundles in a strong midrib, and tracheids with scalariform thickening in diminutive vascular bundles. Moreover, cell size and cell distribution were found to be linked to drought tolerance. Beneath the upper epidermis two layers of large hypodermal cells were present, which serve as water storage tissue. Between the upper and lower hypodermis there was a multilayered and closely packed palisade in contrast to scanty spongy parenchyma. Taking these traits into account, four of seven coconut cultivars were considered relatively tolerant to drought (Naresh Kumar et al., 2000). Drought tolerant cultivars also had more scalariform thickening on tracheids and large sub-stomatal cavities. Despite the latter trait, the cumulative effect of leaflet anatomical adaptations for drought tolerance decrease the contact between the cell and the leaflet internal atmosphere, reducing transpiration rate $(E)$, stomatal conductance $\left(g_{\mathrm{s}}\right)$ and $P_{\mathrm{N}}$, but increasing WUE.

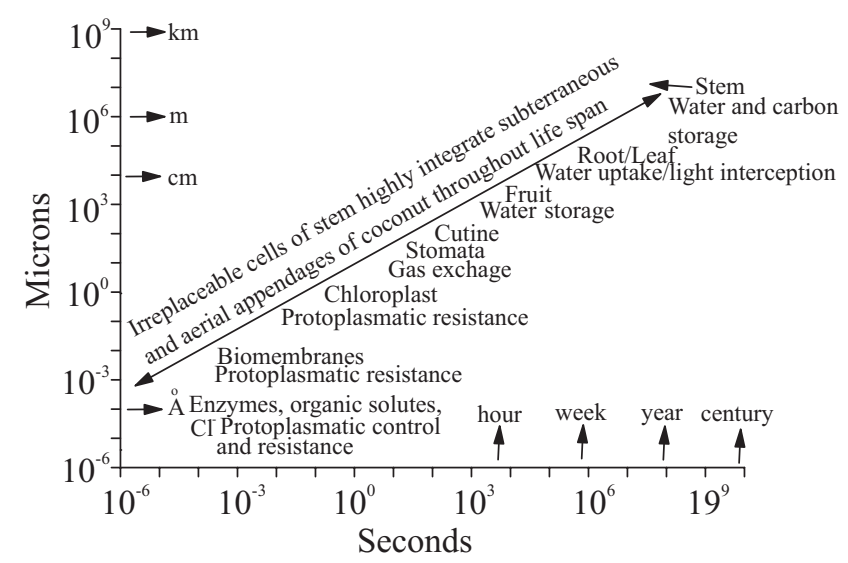

Figure 1. Integrated components, from the atom $(\mathrm{Cl})$ to major plant compartments (stem), which enable the coconut palm to maintain favorable water and carbon balances under water deficit. The unbranched stem (right top) presents mature differentiated cells capable of retaining viability for over a century closely integrating the whole organism. Components are distributed at different space sizes (microns) where physiological processes take place at the corresponding time scale (seconds). See text for details of each physiological process. Time-space scales are based on Osmond and Chow (1988). 
Stored sugar in vegetative organs is important to equilibrate the source-sink relationship in perennial plants. Coconut palm stores sugar in vegetative organs principally as sucrose and, in much smaller amounts, starch, glucose and fructose. The stem is the main site of sugar storage holding around half of all available sugar to sustain coconut palm growth. Sucrose and total sugar concentrations increase from bottom to top and from periphery to the center of the stem, although the concentration gradient is not steep in radial or axial directions, constituting 12-18 kg plant $\mathrm{t}^{-1}$ or 1.9-2.9 $\mathrm{t} \mathrm{ha}^{-1}$ in a commercial plantation of hybrid coconut from Vanuatu (Mialet-Serra et al., 2005). Therefore, the single metabolic stem of coconut constitutes an essential water and carbon buffer for source-sink relationships at the wholeplant level. Irreplaceable cells of stem highly integrate the organism throughout the life span of the plant, connecting subterraneous and aerial appendages (Figure 1).

Palm trees are easily transplanted because the trunk stores considerable quantities of water (Passos and Silva, 1991; Holbrook and Sinclair, 1992) and sugar (Mialet-Serra et al., 2005), besides having a great capacity to produce adventitious roots (Tomlinson, 2006). The fibrous root system (homorhizic) of an adult coconut can protrude as far as $3.0 \mathrm{~m}$ from the trunk, but most roots reach $1.5 \mathrm{~m}$ in length (Avilán and Rivas, 1984; Cintra et al., 1992, 1993). Compacted layers of soil limit the distribution of the coconut root system. On the other hand, high water or nutrient availability at a specific soil site promotes coconut root growth. Therefore, root distribution of coconut is markedly influenced by physical soil properties, irrigation and fertilization practices (Avilán and Rivas, 1984; Cintra et al., 1992, 1993).

The root growth of coconut genotypes may shift to deeper sites in response to dehydration of superficial soil layers. Cintra et al. (1993) concluded that two of six tall genotypes ('Polynesian Tall' and 'Brazilian Tall from Praia do Forte') showed greater ability to produce deeper roots under water stress. The maximum depth from the soil surface reached by coconut roots is usually close to 0.80 $\mathrm{m}$, however, $60-90 \%$ of roots are found in the first $0.5 \mathrm{~m}$ depth (Avilán and Rivas, 1984; Cintra et al., 1993). In 1.5year-old dwarf coconut the effective root zone of absorption is located down to a depth of $0.5 \mathrm{~m}$ and at 1.1 $\mathrm{m}$ from the stem. In 2.5- and 3.5-year-old plants these values were, respectively, 0.4 and $1.2 \mathrm{~m}$, and 0.7 and $1.3 \mathrm{~m}$.
In rainfed 10-year-old plants, the effective root zone of absorption was confined to a depth of $0.7 \mathrm{~m}$ and to a distance of $1.4 \mathrm{~m}$ from the stem (Araujo, 2003).

\section{LEAF PHOTOSYNTHESIS}

Under non-limiting conditions coconut develops a large and highly productive canopy, being capable of an estimated 51 ton ha $^{-1}$ year $^{-1}$ of total dry matter production (Foale, 1993). Low-light intensity and interception, reduced light-use efficiency due to nutrient deficiency, and periodic water stress are the most important factors leading to a much lower actual than potential observed yield.

Short-term responses of coconut to water stress such as low $g_{\mathrm{s}}$ and water potential $(\Psi)$ which often impair $P_{\mathrm{N}}$ and $E$ have been extensively documented (e.g., Repellin et al., 1994; 1997; Passos et al., 1999; Rajagopal and Kasturi Bai, 2002). Carbon assimilation rate is impaired in both tall (Reppellin et al., 1997; Prado et al., 2001) and dwarf genotypes (Passos et al., 2003, 2005; Gomes et al., $2007)$ in response to atmospheric and soil water deficit. Reductions of $P_{\mathrm{N}}$ from 7 to $47 \%$ and from 12 to $67 \%$ have been reported for dwarf and tall genotypes, respectively (Table 1). Drought-induced photosynthetic reductions are initially attributable to limited $\mathrm{CO}_{2}$ diffusion from the atmosphere to the intercellular spaces as a result of stomatal closure (Reppellin et al., 1994, 1997). Nonstomatal factors have been demonstrated to contribute to the reduction in $P_{\mathrm{N}}$ both during a period of severe water deficit and during the recovery phase after resuming irrigation (Gomes, 2006; Gomes et al., 2007). Gomes et al. (2007) used $P_{\mathrm{N}}$ vs $C_{\mathrm{i}}$ relationships to show droughtinduced non-stomatal limitation to $P_{\mathrm{N}}$ in dwarf coconut as indicated by reductions in $\mathrm{CO}_{2}$-saturated $P_{\mathrm{N}}$ and carboxylation efficiency (Figure 2). In addition, the relative stomatal $\left(L_{\mathrm{S}}\right.$, Farquhar and Sharkey, 1982) and mesophyll $\left(L_{\mathrm{m}}\right.$, Jacob and Lawlor, 1991) limitations of $P_{\mathrm{N}}$, as calculated from $P_{\mathrm{N}} v s . C_{\mathrm{i}}$ curves, showed that nonstomatal factors are more important than stomatal during the recovery phase of severe water deficit (Figure 2). It should be noted that the method used in this study for calculating $L_{\mathrm{S}}$ and $L_{\mathrm{m}}$ does not allow one to discriminate between the diffusive and the truly biochemical components of the non-stomatal limitations (Grassi and Magnani, 2005; Galmés et al., 2007; Zhou et al., 2007), so 
the relative contribution of these components remains unsolved for coconut. Nevertheless, the results of Gomes et al. (2007) indicated that photosynthetic capacity in dwarf coconut showed signs of acclimation after repeated drying/recovery cycles, in spite of being colimited by stomatal and non-stomatal factors. In addition, fluorescence measurements demonstrated some degree of chronic photoinhibition in plants of BGD under severe water stress, as indicated by reduction of maximum quantum yield of PSII (Gomes et al., 2007). Considering the reduction in light harvest capacity due to decreasing leaflet pigment content and the similar values of maximum quantum yield of PSII at the end of the experiment (cycle 3), Gomes et al. (2007) suggested that downregulation of photochemistry rather than damage to PSII was occurring. In tolerant genotypes, the enzyme systems protecting the membrane lipids (Shivashankar et al., 1991), as well as the protective action of proline (see below) and high membrane stability as indicated by electrolyte leakage measurements (Gomes, 2006) explain, at least partially, the low sensitivity of the chloroplast membranes to drought stress (Figure 1).

High values of light-saturated photosynthesis $\left(P_{\text {N } \max }\right)$ have been measured in dwarf coconut leaves under nonstress conditions, reaching 14-15 $\mu \mathrm{mol} \mathrm{CO} \mathrm{m}^{-2} \mathrm{~s}^{-1}$ on average (Gomes et al., 2002a,b, 2007). These values fall within the range reported by Larcher (2000) for woody tropical crop plants (from 10 to $15 \mu \mathrm{mol} \mathrm{CO}_{2} \mathrm{~m}^{-2} \mathrm{~s}^{-1}$ ), including species of palm such as oil palm $\left(10 \mu \mathrm{mol} \mathrm{m}^{-2} \mathrm{~s}^{-1}\right.$; Corley, 1983) and Bactris gasipaes (10-12 $\mu \mathrm{mol} \mathrm{m}^{-2} \mathrm{~s}^{-1}$; Oliveira et al., 2002). Extreme values of $P_{\mathrm{N}}$ estimated for oil palm (27-32 $\mu \mathrm{mol} \mathrm{m} \mathrm{m}^{-2} \mathrm{~s}^{-1}$; Lamade and Setiyo, 1996) and coconut (19-20 $\mu \mathrm{mol} \mathrm{m} \mathrm{m}^{-2} \mathrm{~s}^{-1}$; Gomes et al., 2002a) apparently are an overestimation of $P_{\mathrm{N}}$ due to artefacts associated with the hyperbolic models used to adjust the data of light-response curves (Gomes et al., 2006). Coconut $P_{\mathrm{N}}$ becomes light saturated at a value less than half of full direct solar radiation (Foale, 1993). Thus, interception by leaf surfaces oblique to direct-beam radiation increases the light-use efficiency and allows a large leaf area to be illuminated.

\section{WATER RELATIONS AND STOMATAL BEHAVIOR}

Under field conditions, environmental variables determine, to a great extent, the photosynthetic
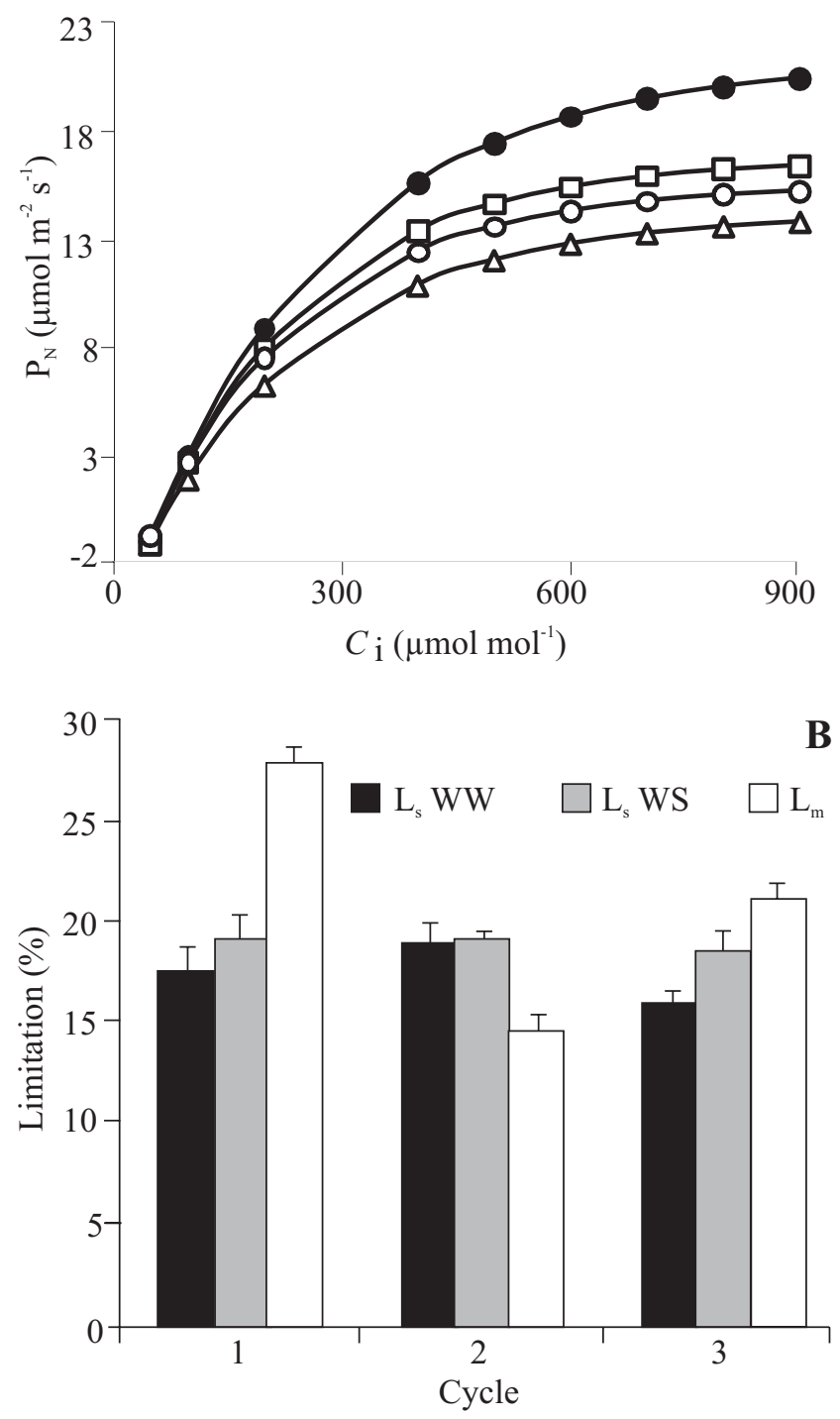

Figure 2. Net photosynthesis $\left(P_{\mathrm{N}}\right)$ vs internal $\mathrm{CO}_{2}$ concentration $\left(\mathrm{C}_{\mathrm{i}}\right)$ relationship $(\mathbf{A})$ and the relative stomatal $\left(L_{\mathrm{s}}\right)$ and mesophyll limitations $\left(L_{\mathrm{m}}\right)$ to $P_{\mathrm{N}}(\mathbf{B})$ in 1year-old plants of Brazilian Green Dwarf coconut recovering from drying/recovery cycles. In each cycle, data were collected $4 \mathrm{~d}$ after re-watering. In the top panel (A) note the reduction of $\mathrm{CO}_{2}$-saturated $P_{\mathrm{N}}$ (potential photosynthetic capacity) and the initial slope (apparent carboxylation efficiency) in water-stressed plants after cycles $1(\Delta), 2(\square)$ and $3(0)$ as compared to well-watered control plants $(\bullet)$. In panel $\mathbf{B}, L_{\mathrm{S}}$ was calculated from $P_{\mathrm{N}} \mathrm{X}$ $C_{\mathrm{i}}$ curves as the difference between $P_{\mathrm{N}}$ at ambient $\mathrm{CO}_{2}$ concentration $\left(\mathrm{C}_{\mathrm{a}} \approx 380 \mu \mathrm{mol} \mathrm{mol}{ }^{-1}\right)$ and at $C_{\mathrm{i}}=C_{\mathrm{a}}$ in both well-watered (WW) and water-stressed (WS) plants; $L_{\mathrm{m}}$ was calculated as the difference between $\mathrm{CO}_{2}$-saturated $P_{\mathrm{N}}$ of WW and WS plants, being zero for WW. Adapted from Gomes et al. (2007). 
performance. Coconut genotypes respond differently to drought stress in relation to the rate of internal dehydration as well as to the rate of gas-exchange recovery upon resuming irrigation. In detached leaflets differences in the dehydration rate can be observed only when $E$ and $g_{s}$ are around zero, suggesting different rates of cuticular transpiration among the genotypes (Repellin et al., 1994). High $E$ in dwarf genotypes resulted in elevated consumption of water as compared to other varieties and hybrids. Tall varieties, in contrast, show a more conservative water use (Voleti et al., 1993). Kasturi Bai et al. (1997) observed that West African Tall (WAT) behaves relatively better than the hybrids under drought conditions, due to lower $g_{\mathrm{s}}\left(0.10 \mathrm{~mol} \mathrm{~m}^{-2} \mathrm{~s}^{-1}\right)$ and, as a consequence, improved tissue water conservation. Notwithstanding, tall cultivars have been considered as drought tolerant when compared to dwarf genotypes. The hybrid PB-121, in turn, presents advantages over other hybrids in both vegetative (girth at collar, rate of leaf emission, leaf area, above-ground dry mass production; Voleti et al., 1988) and reproductive (precocity of flowering, rate of inflorescence production, number of female flowers in the inflorescence; Shivashankar and George, 1993) plant compartments.

There have been important findings about the influence of light, temperature and vapor pressure deficit (VPD) on water relations of coconut, with stomatal regulation playing a pivotal role in the control of water balance (Kasturi Bai et al., 1988, Gomes et al., 2002a). Under adequate soil water availability, stomatal opening of coconut initiates during the first hours of daylight in response to rising irradiance, reaches a peak at midday and decreases rapidly thereafter, accompanying the decreasing irradiance, as noted by Passos and Silva (1990). In fact, the authors observed that the highest $g_{\text {s }}$ and lowest $\Psi$ (-2.6 MPa) occurred at the same time over the course of the day, showing that daily stomatal movements were poorly associated with changes in air temperature and relative humidity, with irradiance being the main controlling factor. From the above, Passos and Silva (1990) suggested that coconut stomata would not exert an effective control of water loss during the hottest and driest hours of the day. However, seasonal and diurnal changes in leaf gas exchange have demonstrated a different response of $g_{s}$ despite a similar response of $\Psi$ in both tall and dwarf varieties (Prado et al., 2001; Passos et al., 2003). During the rainy season, $g_{\mathrm{s}}$ showed maximum values in tall genotypes around $0800 \mathrm{~h}\left(0.25-0.30 \mathrm{~mol} \mathrm{~m}^{-2}\right.$ $\mathrm{s}^{-1}$ ) and decreased thereafter, following the reduction of $\Psi$, despite the increase of irradiance towards midday (Prado et al., 2001). Indeed, stomata closure toward midday was also demonstrated in dwarf genotypes (Passos et al., 2003), even during the rainy season (Passos et al., 2005). Transition from wet to dry season led to reductions in $g_{\mathrm{s}}$ from 44 to $82 \%$ and from 29 to $86 \%$ in dwarf and tall genotypes, respectively (Table 1).

Stomata sensitivity to VPD in dwarf coconut was demonstrated by Gomes et al. (2002a,b) using empirical multiplicative models adjusted from field data of lightresponse curves of $P_{\mathrm{N}}$. According to the authors, the best goodness-of-fit was obtained with those models including a linear function of VPD in the equations of light-response curves of $g_{\mathrm{s}}$. Figure 3 shows the influence of increasing VPD on $g_{s}$ in attached and detached leaflets of Brazilian Green Dwarf (BGD). One minute after detachment, $g_{\mathrm{s}}$ increased under a VPD of 1.0 and $1.5 \mathrm{kPa}$ and decreased under a VPD of $2.0 \mathrm{kPa}$, but remained stable during $15 \mathrm{~min}$ in attached leaflets regardless of

Table 1. Leaf gas exchange in dwarf and tall coconut genotypes growing under field conditions at a rainfed area in Northeast of Brazil. Numbers denote the percentage of decreasing $(-)$ or increasing $(+)$ integrated values $\left(\right.$ day $\left.^{-1}\right)$ of photosynthesis $\left(P_{\mathrm{N}}\right)$, stomatal conductance $\left(g_{\mathrm{s}}\right)$, transpiration $(E)$, and intrinsic water-use efficiency $\left(P_{\mathrm{N}} /\right.$ $g_{\mathrm{s}}$ ) in dry relative to wet season. CRD, Cameroon Red dwarf; GRD, Gramame Red dwarf; GYD, Gramame Yellow dwarf; JGD, Jiqui Green dwarf; BrT, Brazilian tall; WAT, West African tall; TAT, Tahitian Tall; RIT, Rennel Island tall; FJT, Fijian tall; TGT, Tonga tall (adapted from Prado et al., 2001 and Passos et al., 2005).

\begin{tabular}{lrrrr}
\hline Genotype & $P_{\mathrm{N}}$ & $g_{\mathrm{s}}$ & $E$ & $P_{\mathrm{N}} / g_{\mathrm{s}}$ \\
\hline Dwarf & & & & \\
CRD & -6.6 & -44.0 & -1.6 & 68.3 \\
GRD & -30.1 & -68.2 & -35.3 & 119.6 \\
GYD & -27.5 & -59.8 & -21.1 & 80.5 \\
JGD & -46.6 & -82.3 & -62.1 & 197.7 \\
Tall & & & & \\
BrT & -11.7 & -28.7 & -12.3 & 23.7 \\
WAT & -56.6 & -76.9 & -64.8 & 87.3 \\
TAT & -67.3 & -85.5 & -75.5 & 126.0 \\
RIT & -46.2 & -68.4 & -76.1 & 70.2 \\
FJT & -60.1 & -77.1 & -57.3 & 74.5 \\
TGT & -46.0 & -61.7 & -62.0 & 41.3 \\
\hline
\end{tabular}


VPD (Figure 3). The increasing values of $g_{\mathrm{s}}$ in detached leaflets are probably due to water column relaxation after cutting. Although this pattern of response is probably mediated by changes in $\Psi$, these results suggest that working with detached leaflets of coconut may lead to overestimation of $g_{s}$ in $\mathrm{VPD} \leq 1.5 \mathrm{kPa}$ and to underestimation in $\mathrm{VPD} \geq 2.0 \mathrm{kPa}$ (Figure 3). Moreover, no effect of VPD on $g_{s}$ was detected in attached leaflets even under VPD of $2.0 \mathrm{kPa}$. Taking the above information together, we may conclude that, despite causing reduction in $\mathrm{CO}_{2}$ availability, stomata of coconut exert an efficient control of water loss, suggesting the first and the last hours of daylight as the best times for irrigation.

The curvilinear relationship between $P_{\mathrm{N}}$ and $g_{\mathrm{s}}$ (Gomes, 2006) indicates a stomatal limitation of $P_{\mathrm{N}}$ (by decreasing $C_{\mathrm{i}}$ ) below a $g_{\mathrm{s}}$ of $0.2 \mathrm{~mol} \mathrm{~m}^{-2} \mathrm{~s}^{-1}$. Above this value, $P_{\mathrm{N}}$ leveled off, suggesting that it might be possible to manipulate $g_{\mathrm{s}}$ of coconut without causing large $P_{\mathrm{N}}$ reductions, but with improved WUE. In this context, manipulation of water deficit responses, through techniques such as 'partial rootzone drying' (Centritto et al., 2005) and 'regulated deficit irrigation' (Souza et al., 2005), are promising tools that allow the exploration of the plant's long distance signaling system for preventing the development of severe water deficit (Davies et al., 2002).

A positive relationship between vesicular-arbuscular mycorrhizae (VAM) colonization and water relation aspects, as measured by stomatal resistance and $\Psi$, was detected in five cultivars and hybrids of coconut (Thomas et al., 1993). Moreover, drought tolerant genotypes had a greater proportion of roots with VAM colonization and a great number of roots with higher intensities of infection than the sensitive ones (Thomas et al., 1993).

\section{WATER CONSUMPTION AND WATER-USE EFFICIENCY}

Coconut has been considered as extravagant in water consumption. However, as discussed above, there is now strong evidence for efficient stomatal control of plant water status at least under mild to moderate water deficit (Prado et al., 2001; Passos et al., 2003; 2005; Sousa, 2006; Gomes et al., 2007). According to Nogueira et al. (1998) the water requirement of coconut depends on factors such age, height, leaf area, environmental conditions and soil type. Compared to the tall varieties, some evidence suggests that dwarf varieties use water more prodigally due to its elevated transpiration rate (IRHO-CIRAD, 1992), greater number of stomata per unit leaf surface (stomatal frequency) and lower wax content on the leaf surface (Rajagopal et al., 1990), as well as a poorer stomatal control of water loss (Passos and Silva, 1990).
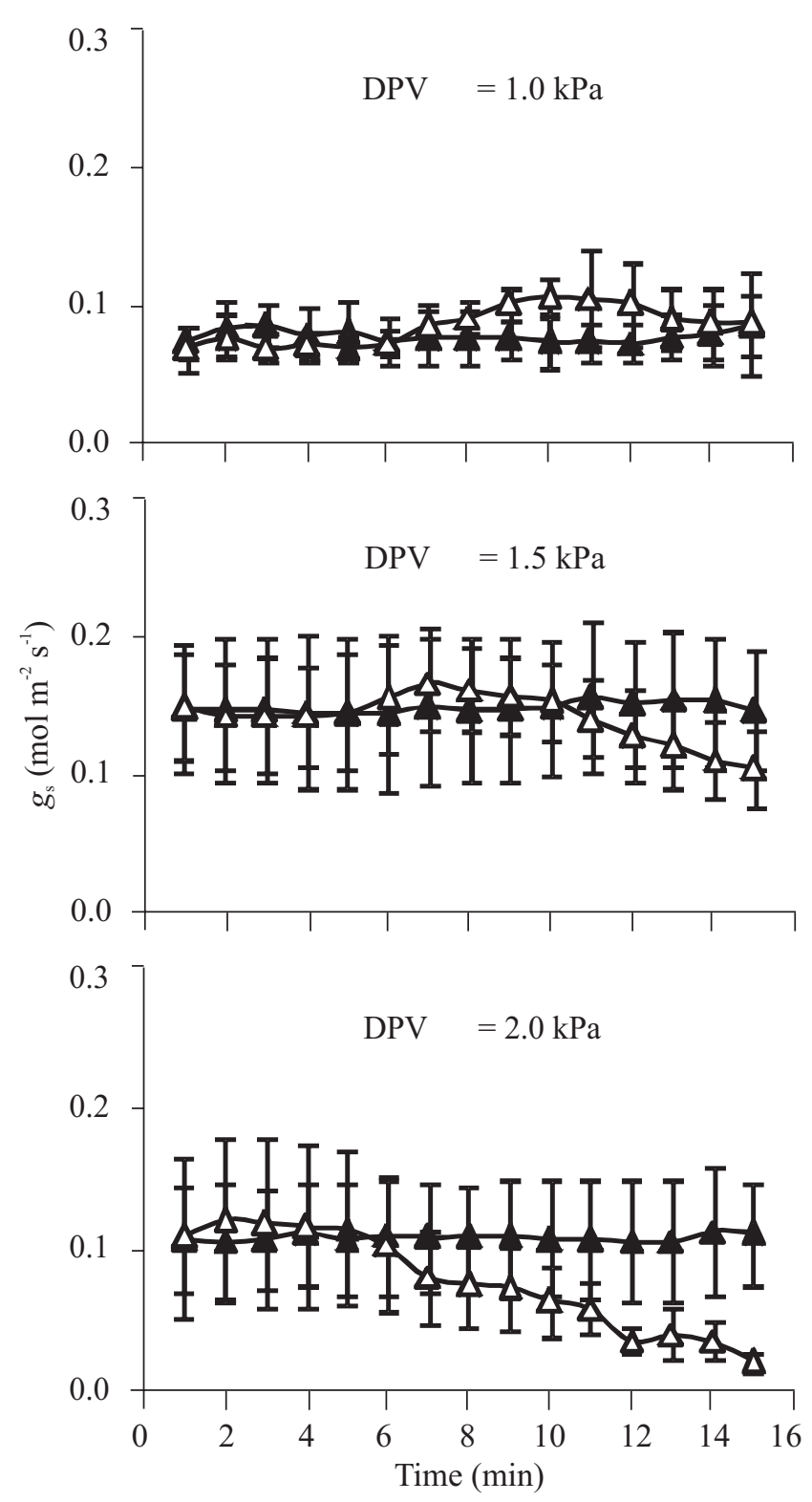

Figure 3. Stomatal conductance of water vapor $\left(g_{\mathrm{s}}\right)$ in attached (solid) and detached (open) leaflets of Brazilian Green Dwarf coconut tree measured under constant vapor pressure deficit (VPD). Leaflets were detached after five of fifteen uninterrupted measurements. Values are mean $( \pm \mathrm{SE})$ of 4-6 replicates. (F. Gomes, unpublished data). 
Recent studies conducted by Sousa (2006) have demonstrated, however, that some dwarf genotypes may show better performance under water deficit than tall ones and hybrids; no turgor loss in leaves of a dwarf cultivar and some hybrids was found during the dry season, which was mainly explained by an effective stomatal control on transpiration.

Jayasekara and Jayasekara (1993) estimated a daily transpiration between 30 and $120 \mathrm{~L}$ by an adult coconut with 35 leaves in the crown $\left(150 \mathrm{~m}^{2}\right.$ of leaf area), depending on soil water content and evaporative demand of the atmosphere. Yusuf and Varadan (1993) estimated the water consumption by tall coconut in India as $115 \mathrm{~L}$ day $^{-1}$ in summer and $55 \mathrm{~L} \mathrm{day}^{-1}$ in winter. Studies with dwarf varieties have suggested a daily water consumption of 8-12 $\mathrm{L} \mathrm{palm}^{-1}$ in the first six months after planting in the field, $12-28 \mathrm{~L} \mathrm{palm}^{-1}$ from 7 to 12 months and 30-55 L palm ${ }^{-1}$ from 13 to 18 months (Miranda et al., 1998). Mean $E$ varied from 0.09 to $1.52 \mathrm{~L} \mathrm{day}^{-1} \mathrm{~m}^{-2}$ leaf area in 3.5-year-old dwarf coconut palms, as estimated by measurements of xylem sap flux density (Araujo, 2003). Taking the mean value of Araujo (2003) (0.8 $\left.\mathrm{L} \mathrm{day}^{-1} \mathrm{~m}^{-2}\right)$ and a leaf area of $140 \mathrm{~m}^{2}$ in dwarf varieties (Ramadasan and Kasturi Bai, 1999), the calculated transpirational water loss $\left(114 \mathrm{~L} \mathrm{day}^{-1}\right)$ agrees with the values reported by Jayasekara and Jayasekara (1993) and is only slightly higher than that reported by Yusuf and Varandan (1993) for tall varieties. This information indicates that the superiority of tall over dwarf varieties under drought conditions, at least in terms of water consumption, should be regarded with caution.

Nevertheless, WUE has been shown to vary among varieties and also among ecotypes of the same variety (Passos et al., 1999; Prado et al., 2001; Gomes et al., 2002a). Passos et al. (1999), comparing three dwarf genotypes, observed that Malayan Yellow Dwarf (MYD) showed better WUE than the other two genotypes (Malayan Red Dwarf, MRD and Brazilian Green Dwarf, BGD). The authors attributed the superiority to (1) higher stomatal sensitivity to changes in $\Psi$, (2) higher $g_{\mathrm{s}}$ during the rainy season, which resulted in higher $P_{\mathrm{N}}$ and better leaf cooling and nutrient uptake capacity due to transpiration, (3) a more developed root system, which leads to higher water-uptake efficiency and (4) a higher rate of leaf and inflorescence emission even during the dry period. In another study Gomes et al. (2002a) showed that MYD was more efficient than BGD in maintaining stomatal opening under high VPD, thereby maintaining a positive rate of carbon assimilation during the hottest hours of the day. The authors observed higher $P_{\mathrm{N}} / g_{\mathrm{s}}$ in MYD $\left(57.0 \mu \mathrm{mol} \mathrm{CO}_{2} \mathrm{~mol}^{-1} \mathrm{H}_{2} \mathrm{O}\right)$ as compared to BGD (36.2 $\left.\mu \mathrm{mol} \mathrm{CO} \mathrm{mol}^{-1} \mathrm{H}_{2} \mathrm{O}\right)$ and, based on the mean maximum values of WUE $\left(3.5 \mu \mathrm{mol} \mathrm{CO}_{2} \mathrm{mmol}^{-1} \mathrm{H}_{2} \mathrm{O}\right)$, the two dwarf genotypes can be considered relatively efficient in their water use when compared to other coconut cultivars and hybrids (from 1.7 to $1.9 \mu \mathrm{mol} \mathrm{CO}_{2} \mathrm{mmol}^{-1} \mathrm{H}_{2} \mathrm{O}$ ) (Kasturi Bai et al., 1996).

The Brazilian Tall variety showed lower $\Psi$ associated with higher $P_{\mathrm{N}}, g_{\mathrm{s}}, E$ and $C_{\mathrm{i}}$ when compared to five other tall genotypes, and was able to remain physiologically active during dry season, despite the absence of an efficient control of water loss (Prado et al., 2001). Probably, this can be achieved through the lower resistance to water flow from roots to leaves, higher ability for maintaining leaf turgor (osmotic adjustment) and/or higher carboxylation efficiency under low $\Psi$. All these mechanisms could be highly integrated to explain the whole plant tolerance to water stress (Figure 1).

\section{BIOCHEMICAL RESPONSES AND OSMOT- IC ADJUSTMENT}

Information concerning the protoplasmic tolerance to drought stress has led to the conclusion that coconut leaves have highly efficient systems that protect cell membranes and their intracellular components. Lipid composition, lipid peroxidation level, and the activities of enzymes related to oxidative stress are good indicators of dehydration tolerance in leaves of coconut. These physiological and biochemical traits usually match the agronomic and morphological data obtained under field conditions.

Modification of total lipid levels and lipid composition involve lipolytic activities, inhibition of lipid synthesis and increasing production of free radicals under stress. The content and composition of membrane polar lipids of coconut leaves change in response to drought conditions (Repellin et al., 1994, 1997). Water deficit induced a reduction in total leaf lipid content, mainly that of the chloroplast membranes, an effect 
particularly expressive in the less drought-tolerant genotypes (Repellin et al., 1994). In addition, an increase in the degree of lipid unsaturation in response to severe drought was also observed, which seems to be related to the maintenance of membrane fluidity, mainly in the chloroplasts (Repellin et al., 1997).

Activities of acid phosphatase and aspartate: oxaloacetate aminotransferase have been shown to increase and that of malate dehydrogenase have been shown to decrease in adult tall coconut when $\Psi$ decreased from -1.0 to $-2.0 \mathrm{MPa}$ (Shinvashankar et al., 1991). Coconut cultivars considered drought tolerant showed a lower level of lipid peroxidation and higher activity of catalase, superoxide dismutase, and peroxidase than cultivars empirically classified as drought susceptible. Indeed, peroxidation level was negatively correlated $\left(R^{2}>0.73\right)$ with activity of antioxidant enzymes (Shinvashankar et al., 1991; Chempakam et al., 1993).

Proline accumulation in leaves of drought-stressed plants and its role as an osmolyte or an osmoprotectant has been the theme of a long-standing debate (Sankar et al., 2007; Seki et al., 2007). For example, whereas Jayasekara et al. (1993) found high levels of proline in leaves of tolerant genotypes during the dry season, the high contents of proline detected in coconut leaflets submitted to dry air (mainly in dwarf varieties) were unlikely to be directly associated with drought tolerance (Voleti et al., 1990; Kasturi Bai and Rajagopal, 2004). In fact, proline contribution to overall osmotic adjustment (a net increase in solute concentration) in ecotypes of BGD was recently demonstrated to be low (Gomes, 2006) because: (1) proline concentration was reduced to control levels upon re-watering whereas osmotic potential did not increase or even decreased in re-watered plants, and (2) the patterns of the two coconut ecotypes studied for proline accumulation did not reflect their relative behavior in terms of osmotic adjustment.

As for proline, results regarding the importance of osmotic adjustment for coconut drought tolerance are also contentious. Osmotic adjustment in ecotypes of BGD coconut under severe water stress $\left(\Psi_{\text {pre-dawn }}=-1.2\right.$ $\mathrm{MPa}$ ) varied from 0.05 to $0.24 \mathrm{MPa}$ (Gomes, 2006). Despite such an adjustment being reported as an important component of drought tolerance mechanisms in various genotypes (Kasturi Bai and Rajagopal, 2000), Gomes (2006) demonstrated its poor effectiveness for turgor maintenance in two dwarf ecotypes, at least under severe water stress conditions. In fact, a great reduction of growth rate was observed in dwarf coconut under severe drought stress (Gomes, 2006).

Chloride plays two important functions in water balance of coconut. On the one hand, $\mathrm{Cl}^{-}$is important for regulating stomatal aperture, in coordinated water flow between six neighboring cells (two guard cells and four subsidiary cells) of the coconut stomatal apparatus. During stomatal pore opening, $\mathrm{K}^{+}$and $\mathrm{Cl}^{-}$ions flow from the subsidiary cell to guard cell. This movement leads to decreases in $\Psi$ of guard cell and, at the same time, increases $\Psi$ of subsidiary cells driving water flow from subsidiary to guard cells (Braconnier and d'Auzac, 1985, 1990). It has been suggested that $\mathrm{Cl}^{-}$is the dominant physiological counterion for $\mathrm{K}^{+}$in controlling stomatal pore aperture of coconut. Chloride deficiency delays stomatal opening by ca. $3 \mathrm{~h}$ in early morning (Braconnier and d'Auzac, 1990). On the other hand, $\mathrm{Cl}^{-}$deficiency reduces the osmoregulation capacity of coconut under water stress. After $69 \mathrm{~h}$ under water stress (-0.5 MPa) imposed by PEG 6000, osmotic potential dropped sharper in the $\mathrm{Cl}^{-}$-sufficient (from -0.93 to $-1.63 \mathrm{MPa}$ ) than in the $\mathrm{Cl}^{-}$-deficient (from -0.83 to $-1.00 \mathrm{MPa}$ ) coconut plantlets (Braconnier and d'Auzac, 1990). Perhaps proline that accumulates under drought might act as an osmoprotectant whereas $\mathrm{Cl}^{-}$acts as an osmolyte (at least at the levels of guard and subsidiary cells). In any case, all these traits are fundamental for the physiological and metabolic integration of drought tolerance mechanisms in coconut (Figure 1).

Leaflet abscisic acid (ABA) concentration increased twofold in dehydrated plants of BGD, being only partially restored to control levels even $8 \mathrm{~d}$ after re-watering (Gomes, 2006). In addition, it was demonstrated that stomata closure in BGD was driven by $\mathrm{ABA}$ and not by the leaf water status at the onset of stress, a response commonly observed in other species (Davies et al., 2002) as well as in other coconut genotypes (Repellin et al., 1997). These results indicate that coconut is able to sense the soil water depletion in the rootzone and sends a stomata-closing signal to the leaves, opening a new line of investigation in drought tolerance research, namely 
non-hydraulic signaling.

\section{PERSPECTIVE FOR NEW INVESTIGATIONS}

Over the last three decades, scientific effort has opened up three main approaches: (1) plant physiology has provided new tools to understand the complex network of drought-related traits and several drought-related traits useful for improving selection efficiency have been proposed; (2) molecular genetics has led to the discovery of a large number of loci affecting yield under drought or the expression of drought tolerance-related traits; and (3) molecular biology has provided genes that are useful as candidate sequences to dissect quantitative trait loci for transgenic approaches. The challenge for future investigations is the integration of molecular genetics with physiology, leading to the identification of the most relevant loci controlling drought tolerance and drought-related traits (Shao et al., 2007; Cattivelli et al., 2008).

In this way, plastid transformation has been quoted as a useful tool for the introduction of important agronomic traits to plants, such as drought tolerance (Lee et al., 2003). Recent studies highlight the importance of generating plastid transformation systems using somatic embryos or embryogenic calli, which might pave the way to engineer the plastid genome of several major crops in which regeneration is mediated through somatic embryogenesis such as coconut (Daniell et al., 2005). On the other hand, it seems convenient to develop tools that permit the evaluation of responses of transgenic plants under different environmental scenarios using virtual plants and modeling techniques before performing true genetic manipulations (Tardieu, 2003). Physiological aspects such as detailed research on ABA signaling pathways, effects of VPD on stomatal behavior and improvements of the partial rootzone drying and deficit irrigation technologies are challenges to be met. Moreover, knowledge on the relative contribution of diffusive (stomatal and mesophyll) conductances and biochemical factors to photosynthetic impairment in coconut under water stress is still scarce.

Acknowledgements: The research conducted by the first author was supported by the Brazilian Government, through its financial agencies (CAPES and CNPq) and by the Government of the State of Bahia (FAPESB and
UESC). CHBAP thanks the research fellowship granted by the Conselho Nacional de Pesquisa Científica (CNPq).

\section{REFERENCES}

Abad M, Noguera P, Puchades R, Maquieira A, Noguera V (2002) Physico-chemical and chemical properties of some coconut coir dusts for use as a peat substitute for containerised ornamental plants. Biores. Technol. 82:241-245.

Aragão WM, Ribeiro FE, Tupinambá EA, Siqueira ER (2002a) Variedades e híbridos de coqueiro. In: Aragão WM (Ed.) Coco: Pós-Colheita. Embrapa Informação Tecnológica, pp.26-34. Brasília, DF. (Série Frutas do Brasil, 29).

Aragão WM, Resende JM, Cruz EMO, Reis CS, Saggin Junior OJ, Alencar JA, Moreira WA, Paula FR, Lima Filho JMP (2002b) Fruto do coqueiro para consumo natural. In: Aragão WM (Ed.) Coco: Pós-Colheita. Embrapa Informação Tecnológica, pp.19-25. Brasília, DF. (Série Frutas do Brasil, 29).

Araujo MC (2003) Demanda hídrica e distribuição de raízes do coqueiro anão verde (Cocos nucifera L.) na região norte fluminense. Campos dos Goytacazes, Universidade Estadual do Norte Fluminense. MSc. thesis.

Avilán LA, Rivas N (1984) Study of the root system of coconut (Cocos nucifera L.). Oleagineux 39:13-23.

Azevedo PV, Sousa IF, Silva BB, Silva VPR (2006). Wateruse efficiency of dwarf-green coconut (Cocos nucifera L.) orchards in northeast Brazil. Agric. Water Manag. 84:259-264.

Braconnier S, d'Auzac J (1985) Étude anatomique et mise en evidence cytologique des mouvements de potassium et de chlore associes à l'ouverture des stomates de palmier à huile et de cocotier. Oleagineux 40:547-551.

Braconnier S, d'Auzac J (1990) Chloride and stomatal conductance in coconut. Oleagineux 45:259-263.

Buschena DE, Perloff JM (1991) The creation of dominant firm market power in the coconut oil market. Am. J. Agric. Econ. 73:1000-1008.

Carrijo OA, Liz RS, Makishima N (2002) Fibra da casca do coco verde como substrato agrícola. Hort. Bras. 20:533-535.

Cattivelli L, Rizza F, Badeck F-W, Mazzucotelli E, Mastrangelo AM, Francia E, Mare C, Tondelli A, 
Stanca AM (2008) Drought tolerance improvement in crop plants: An integrated view from breeding to genomics. Field Crops Res. 105:1-14.

Centritto M, Wahbi S, Serraj R, Chaves MM (2005) Effects of partial rootzone drying (PRD) on adult olive tree (Olea europaea) in field conditions under arid climate. II. Photosynthetic responses. Agric. Ecosyst. Environ. 106:303-311.

Chempakam B, Kasturi Bai KV, Rajagopal V (1993) Lipid peroxidation and associated enzyme activities in relation to screening for drought tolerance in coconut (Cocos nucifera L.). Plant Physiol. Biochem. 20:5-10.

Cintra FLD, Leal LS, Passos EEM (1992) Evaluation of root system distribution in dwarf coconut cultivars. Oleagineux 47:225-234.

Cintra FLD, Passos EEM, Leal LS (1993) Evaluation of root system distribution in Tall coconut cultivars. Oleagineux 48:453-461.

Cloin J (2007) Coconut oil as a fuel in the Pacific Islands. Nat. Res. For. 31:119-127.

Corley RHV (1983) Photosynthesis and age of oil palm leaves. Photosynthetica 17:97-100.

Cuenca MAG, Resende JM, Saggin Junior OJ, Reis CS (2002) Mercado brasileiro do coco: situação atual e perspectivas. In: Aragão WM (Ed) Coco: Pós-Colheita. Embrapa Informação Tecnológica, Brasília, DF. (Série Frutas do Brasil, 29). pp.11-18.

Daniell H, Kumar S, Dufourmantel N (2005) Breakthrough in chloroplast genetic engineering of agronomically important crops. Trends Biotechnol. 23:238-245.

Davies WJ, Wilkinson S, Loveys B (2002) Stomatal control by chemical signaling and the exploitation of this mechanism to increase water use efficiency in agriculture. New Phytol. 153:449-460.

FAO (2005) (Rome, Italy) Core Production data. Captured at http://faostat.fao.org/site/340/DesktopDefault.aspx?Page ID=340 on August 13, 2007.

Farquhar GD, Sharkey TD (1982) Stomatal conductance and photosynthesis. Annu. Rev. Plant Physiol. 33:317345.

Feng LH, Zhang XC (2005) Quantitative expression on drought magnitude and disaster intensity. Nat. Haz. Earth Syst. Sci. 5:495-498.

Foale MA (1993) Physiological basis for yield in coconut. In: Nair MK, Khan HH, Gopalasundaran P, Bhaskara Rao EVV (eds), Advances in Coconut Research and
Development, pp.181-189. Oxford \& IBH Publishing Co. PVT., New Delhi.

Fontes HR, Ribeiro FE, Fernandes MF (2003) Coco: Produção - Aspectos Técnicos. Embrapa Tabuleiros Costeiros, Aracaju. (Série Frutas do Brasil, 27).

Fontes HR, Wanderley M (2006) Situação Atual e Perspectivas para a Cultura do Coqueiro no Brasil. Embrapa Tabuleiros Costeiros, Aracaju (Documentos 94).

Galmés J, Medrano H, Flexas J (2007) Photosynthetic limitations in response to water stress and recovery in Mediterranean plants with different growth forms. New Phytol. 175:81-93.

Gomes FP (2006) Trocas gasosas em coqueiro anão-verde submetido a ciclos de deficiência hídrica. Viçosa, Universidade Federal de Viçosa. PhD thesis.

Gomes FP, Mielke MS, Almeida A-AF, Muniz WS (2002a) Leaf gas exchange in two dwarf coconut genotypes in the southeast of Bahia State, Brazil. Coconut Res. Develop. 18:37-55.

Gomes FP, Mielke MS, Almeida A-AF (2002b) Leaf gas exchange of green dwarf coconut (Cocos nucifera $\mathrm{L}$. var. nana) in two contrasting environments of the Brazilian north-east region. J. Hort. Sci. Biotechnol. 77:766-772.

Gomes FP, Oliva MA, Mielke MS, Almeida A-AF, Leite HG (2006) Photosynthetic irradiance-response in leaves of dwarf coconut palm (Cocos nucifera L. 'nana', Arecaceae): Comparison of three models. Sci. Hort. 109:101-105.

Gomes FP, Oliva MA, Mielke MS, Almeida A-AF, Leite HG, Aquino LA (2007) Photosynthetic limitations in leaves of young Brazilian Green Dwarf coconut (Cocos nucifera L. 'nana') palm under well-watered conditions or recovering from drought stress. Environ. Exp. Bot. in press: doi:10.1016/j.envexpbot.2007.08.006.

Grassi G, Magnani F (2005) Stomatal, mesophyll conductance and biochemical limitations to photosynthesis as affected by drought and leaf ontogeny in ash and oak trees. Plant Cell Environ. 28:834-849.

Hallé F, Oldeman R, Tomlinson P (1978) Tropical Trees and Forest. An Architectural Analysis. SpringerVerlag, New York.

Harries HC (1978) The evolution, dissemination and classification of Cocos nucifera L. Bot. Rev. 44:265- 
319.

Henderson FM (2006) Morphology and anatomy of palm seedlings. Bot. Rev. 72:273-329.

Holbrook NM, Sinclair TR (1992) Water balance in the arborescent palm Sabal palmetto stem structure, tissue water release properties and leaf epidermal conductance. Plant Cell Environ. 15:393-399.

IRHO-CIRAD (1992) Coconut-Study of yield factors. Oleagineux 47:324-337.

Jacob J, Lawlor DW (1991) Stomatal and mesophyll limitations of photosynthesis in phosphate deficient sunflower, maize and wheat plants. J. Exp. Bot. 42:10031011.

Jayasekara KS, Jayasekara C (1993) Efficiency or water use in coconut under different soil/plant management systems. In: Nair MK, Khan HH, Gopalasundaran P, Bhaskara Rao EVV (eds) Advances in Coconut Research and Development, p.427. Oxford \& IBH Publishing Co Pvt. Ltd, New Delhi.

Jayasekara KS, Ranasinghe CS, Mathes DT (1993) Screening for high yield and drought tolerance in coconut. In: Nair MK, Khan HH, Gopalasundaran P, Bhaskara Rao EVV (eds) Advances in Coconut Research and Development, p.209-218. Oxford \& IBH Publishing Co Pvt. Ltd., New Delhi.

Kasturi Bai KV, Rajagopal V (2000) Osmotic adjustment as a mechanism for drought tolerance in coconut (Cocos nucifera L.). Indian J. Plant Physiol. 5:320-323.

Kasturi Bai KV, Rajagopal V (2004) Is stress-induced proline accumulation an indicator of leaf water status in coconut? J. Plant. Crops. 32(suppl.):1-4.

Kasturi Bai KV, Voleti SR, Rajagopal V (1988) Water relations of coconut palms as influenced by environmental variables. Agric. For. Meteorol. 43:193-199.

Kasturi Bai KV, Rajagopal V, Prabha CD, Ratnambal MJ, George MV (1996) Evaluation of coconut cultivars and hybrids for dry matter production. J. Plant. Crops 24:2328.

Kasturi Bai KV, Rajagopal V, Balasimha D, Gopalasudaram P (1997) Water relations, gas exchange and dry matter production of coconut (Cocos nucifera L.) under irrigated and non-irrigated conditions. Coconut Res. Develop. 13:45-58.
Kurup VVGK, Voleti SR, Rajagopal V (1993) Influence of weather variables on the content and composition of leaf surface wax in coconut. J. Plant. Crops 2:71-80.

Lamade E, Setiyo E (1996) Variation in maximum photosynthesis of oil palm in Indonesia: comparison of three morphologically contrasting clones. Plant. Rech. Develop. 3:429-438.

Lambers H, Chapin III FS, Pons TL (1998) Plant Physiological Ecology. Springer-Verlag, New York.

Larcher W (2000) Ecofisiologia Vegetal. Rima Artes e Textos, São Carlos.

Lee S-B, Kwon H-B, Kwon S-J, Park S-C, Jeong M-J, Han SE, Byun M-O, Daniell H (2003) Accumulation of trehalose within transgenic chloroplasts confers drought tolerance. Mol. Breed. 11:1-13.

Levang P (1988) Coconut is also a sugar crop. Oleagineux 43:159-164.

Lorenzi H, Souza HM, Medeiros-Costa JT, Cerqueira LSC, Behr NV (1996) Palmeiras no Brasil: Nativas e Exóticas. Editora Plantarum, São Paulo.

Mathew AC, Singh TV, Bosco SJD (2000) Coconut timber utilization. Indian Coconut J. 31:51-54.

Mialet-Serra I, Clement A, Sonderegger N, Roupsard O, Jourdan C, Labouisse J-P, Dingkuhn M (2005) Assimilate storage in vegetative organs of coconut (Cocos nucifera). Exp. Agric. 41:161-174.

Miranda FR, Oliveira VA, Santos FJS (1998) Desenvolvimento de plantas jovens de coqueiro anão (Cocos nucifera L.) submetidos a diferentes regimes de irrigação. EMBRAPA-Agroindústria Tropical, Fortaleza.

Naresh Kumar S, Rajagopal V, Karun A (2000) Leaflet anatomical adaptations in coconut cultivars for drought tolerance, pp.225-229. Recent Advances in Plantation Crops Research, CPCRI contribution n.995.

Nogueira LC, Nogueira LRQ, Miranda FR (1998) Irrigação do coqueiro. In: Ferreira JMS, Warwick DRN, Siqueira LA (eds.), A cultura do Coqueiro no Brasil, pp.159-187.. EMBRAPA, Brasília.

Nunes MUC (2002) Fibra e pó da casca de coco: produtos de grande importância para a indústria e agricultura. In: Aragão WM (Ed.) Coco: Pós-Colheita, pp.66-71. Embrapa Informação Tecnológica, Brasília (Série Frutas do Brasil, 29).

Ohler JG (1999a) Historical background. In: Ohler JG (ed), Modern Coconut Management: Palm Cultivation and 
Products, pp.3-4. The Food and Agriculture Organization of the United Nations (FAO). Intermediate Technology Publications, London.

Ohler JG (1999b) Climate and soils. In: Ohler JG (ed), Modern Coconut Management: Palm Cultivation and Products, pp.35-53. The Food and Agriculture Organization of the United Nations (FAO). Intermediate Technology Publications, London.

Oliveira MAJ, Bovi MLA, Machado EC, Gomes MMA, Habermann G, Rodrigues JD (2002) Fotossíntese, condutância estomática e transpiração em pupunheira sob deficiência hídrica. Sci. Agric. 59:59-63.

Osmond CB, Chow WS (1988) Ecology of photosynthesis in the sun and shade: summary and prognostications. Austr. J. Plant Physiol. 15:19.

Passos EEM (1998) Ecofisiologia do coqueiro. In: Ferreira JMS, Warwick DRN, Siqueira LA (eds), A Cultura do Coqueiro no Brasil, pp.65-72. EMBRAPA-SPI, Brasília.

Passos EEM, Silva JV (1990) Fonctionnement des stomates de cocotier (Cocos nucifera) au champ. Can. J. Bot. 68:458-460.

Passos EEM, Silva JV (1991) Détermination de l'état hydrique du cocotier par la méthode dendrométrique. Oleagineux 46:233-238.

Passos EEM, Prado CHBA, Leal MLS (1999) Condutância estomática, potencial hídrico foliar e emissão de folhas e inflorescências em três genótipos de coqueiro anão. Agrotrópica 11:147-152.

Passos EEM, Passos CD, Aragão WM (2003) Trocas gasosas em genótipos de coqueiro anão sob condições de deficiência hídrica. Aracaju, Embrapa Tabuleiro Costeiros (Comunicado Técnico 11).

Passos CD, Passos EEM, Prado CHBA (2005) Comportamento sazonal do potencial hídrico e das trocas gasosas de quatro variedades de coqueiroanão. Rev. Bras. Frutic. 27:248-254.

Prado CHBA, Passos EEM, Moraes JAPV (2001) Photosynthesis and water relations of six tall genotypes of Cocos nucifera in wet and dry seasons. South Afr. J. Bot. 67:169-176.

Rajagopal V, Kasturi Bai KV, Voleti SR (1990) Screening of coconut genotypes for drought tolerance. Oleagineux 45:215-223.

Rajagopal V, Shivashankar S, Mathew J (1996) Impact of dry spells on the ontogeny of coconut fruits and its relation to yield. Plant. Rech. Dévelop. 3:251-255.
Rajagopal V, Kasturi Bai KV (1999) Water relations and screening for drought tolerance. In: Rajagopal V, Ramadasan A (eds), Advances in Plant Physiology and Biochemistry of Coconut Palm, pp.56-70. Asian and Pacific Coconut Community. Jakarta.

Rajagopal V, Kasturi Bai KV (2002) Drought tolerance mechanism in coconut. Burot. Bull. 17:21-22.

Ramadasan A, Kasturi Bai KV (1999) Leaf area, dry matter production and yield. In: Rajagopal V, Ramadasan A (eds), Advances in Plant Physiology and Biochemistry of Coconut Palm, pp.30-46. Asian and Pacific Coconut Community, Jakarta.

Ranasinghe CS, Waidyanatha UPS (2003) Ethrel stimulation of inflorescence sap flow in tapped coconut (Cocos nucifera) palms. Exp. Agric. 39:161166.

Repellin A, Daniel C, Zuily-Fodil Y (1994) Merits of physiological tests for characterizing the performance of different coconut varieties subjected to drought. Oleagineux 49:155-168.

Repellin A, Pham Thi AT, Tashakorie A, Sahsah Y, Daniel C, Zuily-Fodil Y (1997) Leaf membrane lipids and drought tolerance in young coconut palms (Cocos nucifera L.). Eur. J. Agron. 6:25-33.

Sankar B, Jaleel CA, Manivannan P, Kishorekumar A, Somasundaram R, Panneerselvam R (2007) Droughtinduced biochemical modifications and proline metabolism in Abelmoschus esculentus (L.) Moench. Acta Bot. Croat. 66:43-56.

Satyabalan K (1997) Coconut Varieties and Cultivars: Their Classification. Asian and Pacific Coconut Community, Jakarta.

Seki M, Umezawa T, Urano K, Shinozaki K (2007) Regulatory metabolic network in drought stress responses. Curr. Opin. Plant Biol. 10:296-302.

Shao H-B, Guoc Q-J, Chuc L-Y, Zhao X-N, Suc Z-L, Hud YC, Cheng J-F (2007) Understanding molecular mechanism of higher plant plasticity under abiotic stress. Colloids Surfac. B: Biointerfaces 54:37-45.

Shivashankar S, Kasturi Bai KV, Rajagopal V (1991) Leaf water potential, stomatal resistance and activity of enzymes during development of moisture stress in the coconut palm. Trop. Agric. 68:106-10.

Shivashankar S, George KM (1993) Seedling characters related to precocity of flowering and early yield in coconut hybrids. J. Plant. Crops 21(suppl.):355-359. 
Shivashankar S, Nagaraja KV, Voleti SR, Kasturi Bai KV (1993) Biochemical changes and leaf water status of coconut genotypes differing in drought tolerance. In: Nair MK, Khan HH, Gopalasundaran P, Bhaskara Rao EVV (eds), Advances in Coconut Research and Development, pp.253-254. Oxford \& IBH Publishing Co Pvt. Ltd., New Delhi.

Silva Junior CD, Passos EEM, Gheyi HR (2002) Aplicação de água salina no desenvolvimento e comportamento fisiológico do coqueiro. Rev. Bras. Eng. Agric. Amb. 6:39-44.

Siqueira LA, Aragão WM, Tupinambá EA (2002) A Introdução do Coqueiro no Brasil, Importância Histórica e Agronômica. Embrapa Tabuleiros Costeiros, Aracaju (Documentos, 47).

Sousa SM (2006) Comportamento sazonal de sete genótipos de coqueiro (cocos nucifera L.) nas condições ecológicas de Mojú, Estado do Pará. Manaus, Universidade Federal Rural do Amazonas, $\mathrm{PhD}$ thesis.

Souza CR, Maroco JP, Santos TP, Rodrigues ML, Lopes C, Pereira JS, Chaves MM (2005) Control of stomatal aperture and carbon uptake by deficit irrigation in two grapevine cultivars. Agric. Ecosys. Environ. 106:261-274.

Tan RR, Culaba AB, Purvism MRI (2004) Carbon balance implications of coconut biodiesel utilization in the Philippine automotive transport sector. Biom. Bioen. 26:579-585.

Tardieu F (2003) Virtual plants: modeling as a tool for the genomics of tolerance to water deficit. Trends Plant Sci. 8:9-14.

Thomas GV, Rajagopal V, Bopaiah BM (1993) VAmycorrhizal association in relation to drought tolerance in coconut. J. Plant. Crops (Suppl. 1):98-103.
Tomlinson PB (1961) Anatomy of the Monocotyledons II: Palmae. Oxford University Press.

Tomlinson PB (2006) The uniqueness of palms. Bot. J. Linn. Soc. 151:5-14.

van Dam JEG, van den Oever MJA, Keijsers ERP (2004) Production process for high density high performance binderless boards from whole coconut husk. Ind. Crops Prod. 20:97-101.

Villalobos E, Umaña CH, Chinchilla C (1992) Estado de hidratación de la palma aceitera, en respuesta a la seguía en Costa Rica. Oleagineux 47:1-7.

Voleti SR, Shivashankar S, Rajagopal V (1988) Comparison of physiological and biochemical parameters of coconut hybrid seedlings. J. Plant. Crops 18 (Suppl.):104-107.

Voleti SR, Kasturi Bai KV, Rajagopal V, Shivashankar S (1990) Relative water content and proline accumulation in coconut genotypes under moisture stress. J. Plant. Crops 18:88-95.

Voleti SR, Kasturi Bai KV, Rajagopal V (1993) Water potential in the leaves of coconut (Cocos nucifera L.) under rainfed and irrigated conditions. In: Nair MK, Khan HH, Gopalasundaran P, Bhaskara Rao EVV (eds), Advances in Coconut Research and Development, pp.243-245. Oxford \& IBH Publishing, New Delhi.

Walther GR, Gritti ES, Berger S, Hickler T, Tang Z, Sykes MT (2007) Palms tracking climate change. Globla Ecol. Biogeogr. (in press):DOI: 10.1111/j.1466-8238.2007. 00328.x, available online at www.blackwellpublishing. com/geb

Yusuf M, Varadan KM (1993) Water management studies on coconut in India. In: Nair MK, Khan $\mathrm{HH}$, Gopalasundaran P, Bhaskara Rao EVV (eds), Advances in Coconut Research and Development, pp.337-346. Oxford \& IBH Publishing, New Delhi.

Zhou Y, Lam HM, Zhang J (2007) Inhibition of photosynthesis and energy dissipation induced by water and high light stresses in rice. J. Exp. Bot. 58:1207-1217. 